\title{
MARITIME POLICY INTEGRATION MODEL AT NATUNA ON THE DEFENSE AND SECURITY PERSPECTIVE
}

\author{
Rapang Isak*, Postgraduate Student \\ Fanani Z., Widagdo Setyo, Domani Tjahjanulin, Lecturers \\ University of Brawijaya, Malang, Indonesia \\ *E-mail: ir.admiral4701@gmail.com
}

\begin{abstract}
Natuna Regency is one of the border areas that has the potential of Fisheries Resources (one million tons/year), agriculture, plantations and D-Alpha gas fields located in $225 \mathrm{~km}$ to the North of Natuna Island in ZEEI (Indonesian Exclusive Economic Zone) with a total reserve of 222 Trillion Cubic Feet and hydrocarbon gas of 46 TCT which is one of the largest sources in Asia. The problem that have not been resolved are the Indonesia-Vietnam border in the North Natuna Sea and China's claims based on the Nine Dash Line have caused overlapping with the Indonesian Exclusive Economic Zone (EEZ) in North Natuna. There are still regional violations and fish theft by Vietnamese and Chinese fishermen in it escorted by repeated government or Coast Guard vessels. Therefore, a maritime policy model is needed that can synergize maritime security agencies in law enforcement and state sovereignty at sea for defense and security in Natuna to support national security. This research uses Public Policy Theory and Legal Policy Theory. Qualitative research methods used through observation, interviews, streethnography, ethnographic interviewing and elite interviewing and literature review. The results suggest a model of maritime policy integration in Natuna with the Navy and Air Force as leading sectors that synergize with other marine security agencies such as the KKP and Indonesia Maritime Security Agency in cracking down on any activities of regional violations and theft of living natural resources (fish) in North Natuna and ZEEI through a military approach and non-military approach in supporting national defense.
\end{abstract}

\section{KEY WORDS}

Military and non-military defense, ipoleksosbud security, maritime policy integration.

One of the government's political agenda in addressing the geographical condition of Indonesia as an archipelagic country is characterized by the archipelago and becoming the largest maritime country in the world with the launching of Indonesia's vision as a World Maritime Axis with five pillars. The idea of Indonesia as an archipelago was accepted consensus by all nations of the world represented by the United Nations with the signing of the United Nations Convention on the United Nations Convention on the Law of the Sea (UNCLOS 1982) and by the Government of Indonesia ratified this convention with Republican Laws Indonesia number 17 of 1985. Indonesia's geographical location among the world's crosses makes Indonesia the center of world trade and economy. Indonesia's strategic position plays an important role especially in the stability of the economic and military fields and there are specific obstacles for Indonesia and countries in various regions to take advantage of trade traffic by sea. Aside from being a world economic center by utilizing its sea lanes, Indonesia has abundant marine resource potential. It is estimated that Indonesia's marine economy reaches 1.2 trillion US dollars / year consisting of capture fisheries, aquaculture, fishery product processing industries, marine biotechnology industry, mining and energy, marine tourism, magrove forests, sea communications, marine resources of the islands small, industrial and maritime services, non-conventional natural resources (Dahuri, 2001)

Indonesia as an archipelago has ratified on UNCLOS 1982 so that Indonesia has territorial waters which include Indonesian waters (inland waters, archipelagic waters and territorial seas), Additional Zones, Exclusive Economic Zones and Continental Shelf. Indonesia has sovereignty in the inland waters, archipelagic waters and territorial sea as 
wide as 12 nautical miles measured from the baselines of the Indonesian archipelago. Indonesia has sovereign rights in the territorial waters including the air space above and the seabed below and the natural resources contained therein. All Indonesian national laws and regulations are fully enforced in all Indonesian territorial waters, but their implementation must take into account the provisions of International Sea Law and other International Laws. Whereas Indonesia's sovereign rights are the rights of use and management of certain matters in the zone established by international UNCLOS 1982 law outside 12 territorial sea nautical miles and in that region Indonesia's full power does not apply. The area where these rights are valid is known as the jurisdiction of Indonesia, not the territory of Indonesia. This jurisdiction is known as a special and limited jurisdiction for additional zones and exclusive jurisdiction for exclusive economic zones and continental shelf (Muchtar and Etty, 2010). Because the additional zone is outside the territorial sea of 12 miles, Indonesia does not have full sovereignty over the zone but has sovereign rights or management and use rights in the fields of fiscal, immigration, customs and sanitary / health including the implementation of supervision and enforcement of violations of the four fields.

According to article 55 of UNCLOS 1982 states that Exclusive Economic Zone is an area of the sea that is located outside and adjacent to the territorial sea. This shows that the Exclusive Economic Zone is a sea zone that is outside or not a national territory. According to I Wayan Parthina that in the Exclusive Economic Zone, a coastal country has certain rights and jurisdictions (Parthiana, 2003). Why is it called the Exclusive Economic Zone and where are the Exclusive aspects? According to I Wayan Parthina the exclusive aspect is the rights and jurisdiction in the name of the zone specifically or exclusively granted to the relevant coastal state, not to the state or other legal subjects. So that the exclusive aspect intended in the Exclusive Economic Zone based on article 55 of UNCLOS 1982 is to provide sovereign rights to coastal states for the purposes of exploitation, exploration, conservation and management of natural and biological resources, from waters on the seabed or from the bottom of the sea and the land beneath and in connection with all other activities for the purposes of exploration and economic exploitation of the zone, such as energy and water production, currents and wind. According to G. Kartasapoetra and RG Kartasapoetra (1984) with the ratification of UNCLOS 1982 by Indonesia, then: First, Indonesia has the right of consulate to determine and implement the provisions applicable to the 200-mile Exclusive Economic Zone route in accordance with the provisions of International Law. Secondly, the determination of the boundaries of the Exclusive Economic Zone is an important policy, because no boundaries of the Exclusive Economic Zone are now determined, the possibility of disputes in the future will always be there. Third, the establishment of the Exclusive Economic Zone boundary for Indonesia means an increase in waters and seabed over 2.5 million $\mathrm{km}^{2}$. Fourth, the rescue and security of marine resources as the waters and the seabed are expanding is a challenge that must be resiliently faced for the safety of Defense and Security and the honor of the prestige of the state and nation of Indonesia. Whereas on the basis of continents, the exploration and exploitation of natural resources is based on continents fully the authority of coastal countries, taking into account the limitations issued by the coastal state governments and the possibility of misunderstanding or misunderstanding that results in disputes between interests in the utilization of natural resources., will be a serious concern for the government to solve it (Subagyo, 2002).

Regarding the Indonesian maritime zone, especially in the Exclusive Economic Zone and the Continental takeoff in the North Natuna Sea at this time. Indonesia - Vietnam sea boundary disputes in North Natuna Sea that have not yet met an agreement have an impact on the activities of territorial violations and theft of fish at the EEZ in North Natuna by Vietnamese fishing vessels escorted by government vessels or Coast Guard which have occurred repeatedly from 2015 to 2017, 49 Vietnamese fishing vessels have been captured by Indonesian maritime security agencies who carry out illegal fishing (Staf Operasi Koarmada, 2018). Likewise, China with territorial claims made by issuing a Nine Dash Line map in 1947 caused overlapping with the EEZ in North Natuna and led to regional violations and fish theft by Chinese fishing vessels which were also escorted by government vessels 
and ships its military, which has occurred repeatedly since 2010, 2015, 2016 and ended in early 2020 .

Although Indonesia is a country that has not a claim on the North Natuna Sea, but Indonesia has several interests in that area. The first interest is to protect the adjacent Natuna sovereignty in the North Natuna Sea because the Natuna region is a strategic region which is rich in natural resources. According to K.J. Holsti sovereignty is included in the core values of national interests, which is something that is considered the most important for a country related to security, defense and sovereignty (Holsti, 1970). The state will do anything to maintain core values. Indonesia feels sovereignty in Natuna is threatened by illegal fish theft by China. Therefore, Indonesia's firm attitude towards China in Natuna waters can be understood within the framework of the interests of these core values. Sovereignty in Natuna waters is more important than economic interests, which according to Holsti is categorized as middle range interest. Indonesia's second interest in Natuna is to maintain regional stability in Southeast Asia. If the Southeast Asian region is not safe, it will bring influence to countries in the Southeast Asia region, including Indonesia.

Therefore, the government's position expressly conveyed that the resolution of the problem in North Natuna with Vietnam and China would be carried out decisively through defense diplomacy even the Minister of Foreign Affairs of the Republic of Indonesia Retno LP Marsudi had expressly stated the attitude that the Chinese fishing vessels violated the ZEEI (Indonesian Exclusive Economic Zone) in North Natuna, the ZEEI (Indonesian Exclusive Economic Zone) area in North Natuna has been established based on UNCLOS 1982, China is one of the members who approved UNCLOS 1982, Indonesia has never recognized the Nine Dash Line. In line with this, the Indonesian National Army (TNI) as a tool of the state in the field of defense which in carrying out its duties based on policies and political decisions of the country responds quickly to any actions of foreign vessels both foreign fishing vessels and government vessels entering the ZEEI (Indonesian Exclusive Economic Zone) region in North Natuna by enforcing the law and state sovereignty at sea, in accordance with the mandate of the Law of the Republic of Indonesia Number 34 of 2004 which concerned on TNI. The task of national defense at sea that carried out by the Navy is based on Article 9, that First, Carrying out the duties of the Indonesian Navy in the field of defense. Second, Uphold the law and maintain security in the sea territories of national jurisdictions in accordance with the provisions of national law and international law which have been ratified. Third, Carry out Navy diplomacy in order to support foreign policy set by the government. Fourth, Carry out the tasks of the Navy in the construction and development of the strength of the sea dimension. Fifth, Carry out empowerment of marine defense areas. Those tasks are in accordance to UNCLOS 1982, which stipulates that actions which taken by military vessels can be justified on matters that related to the strengthening of sovereign rights and law enforcement as mentioned in article 73, article 110, article 111 and article 224 of UNCLOS 1982. In carrying out this task the support of the Air Force as a sensing through the title of an aircraft is needed so that it can be an extension of the KRI task force in carrying out patrols. While the security tasks carried out by non-military (KPLP, Customs, Polairud, KKP and Indonesia Maritime Security Agency) as supporting partners in the field of state security, so the two forces must support each other and provide information about the situation and condition of the sea, especially in the Natuna region and the Economic Zone Exclusively Indonesia in North Natuna. At present the two forces, namely military force (Navy and Air Force) and non-military forces in the form of government vessels (KPLP, Customs, Polairud, KKP and Indonesia Maritime Security Agency) are considered not integrated and synergistic in carrying out functions, tasks and its role so that it seems more likely to prioritize each sector ego, this is the focus of research so that it can provide an input to the government to produce a model of government policy in the form of a model of policy integration in the maritime sector in Natuna in the perspective of defense and security so that it can support national defense. 


\section{METHODS OF RESEARCH}

This research is a field research with qualitative methods. This type of field research is intended that the data that are the object of research are the materials that are dominantly in the field while accommodating information that comes from selective library sources. Data collection techniques are carried out through observation, interviews, streethnography, ethnographic interviewing and elite interviewing as well as sources of literature, and then the data is processed to obtain a result that can answer the research problem. Primary data collection is useful to produce data sources that directly provide data to data collectors or researchers (Sugiyono, 2004). Informants or informants in this study consisted of various officials involved in marine defense and security and served in maritime security agencies or government agencies such as the Navy, Indonesia Maritime Security Agency, KKP, Polairud, Customs, KPLP and officials of the Natuna Regency Government and community leaders in Natuna. The focus of this research is based on the formulation of the research problem. This research consists of two research focuses; the first research focus is military and non military defense in the maritime policy integration model in Natuna from a defense and security perspective. The second research focus is ideological security, political security, economic security, and socio-cultural security in the model of maritime policy integration in Natuna from a defense and security perspective.

\section{RESULTS AND DISCUSSION}

Indonesia's Maritime Policy was prepared with reference to the Vision of Indonesian Development as stipulated in Law Number 17 of 2007 concerning the National Long-Term Development Plan 2005-2025 and Law of the Republic of Indonesia Number 32 of 2014 concerning Maritime Affairs. Indonesia's Maritime Vision is to make Indonesia a World Maritime Axis, which is to become a maritime country that is developed, sovereign, independent, strong, and able to make a positive contribution to regional and world security and peace in accordance with national interests. In order to realize the vision of Indonesian Waters, the government arranged the mission of Indonesian Ocean Policy, such as:

- Optimized and sustainable management of marine resources;

- Development of quality human resources, reliable marine science and technology;

- Building strong marine defense and security;

- The enforcement of sovereignty, law and safety at sea;

- Implementation of good marine governance;

- Realization of the welfare of coastal communities and small islands that are evenly distributed;

- Realization of economic growth and competitive marine industry;

- Development of reliable marine infrastructure;

- Completion of rules regarding sea spatial planning;

- Implementation of the protection of the marine environment;

- Implementation of maritime diplomacy; and

- The formation of identity and maritime culture.

To fulfill the vision and mission of Indonesia's maritime policy, it is necessary to strengthen the defense and security sector, especially in the maritime sector, given the Indonesian territory that consists of Indonesian islands and geographical borders with ten countries so that the importance of strengthening border areas from the defense and security aspects.

Natuna Regency is one of the border areas surrounded by the South China Sea (July 14, 2017 changed its name by the Indonesian government to the North Natuna Sea) has its own uniqueness because the North Natuna Sea in accordance with international law is a sea zone that intersects the boundaries of the EEZ at several countries in Southeast Asia such as Malaysia and Vietnam in the west and southwest, the Philippines in the east, Brunei Darussalam and Malaysia in the southeast and Indonesia in the south. Regarding the 
Indonesia - Vietnam sea border area in the North Natuna Sea which has yet to be resolved despite several meetings between the two governments. At the $12^{\text {th }}$ (twelfth) meeting between Indonesia and Vietnam in Surabaya on 20 to 21 August 2019, the two countries agreed to arrange temporary arrangements in the ZEEI (Indonesian Exclusive Economic Zone) overlap in North Natuna as part of efforts to avoid incidents of the two state apparatus through strengthening communication, restraint and restrictions on fishing activities. However, an agreement has not yet been reached in determining the EEZ boundary line, so as a reference for law enforcement officers at sea regarding the use of the sea then it can use 354 sea maps that already have the EEZ borderline drawings of Indonesian unilateral claims.

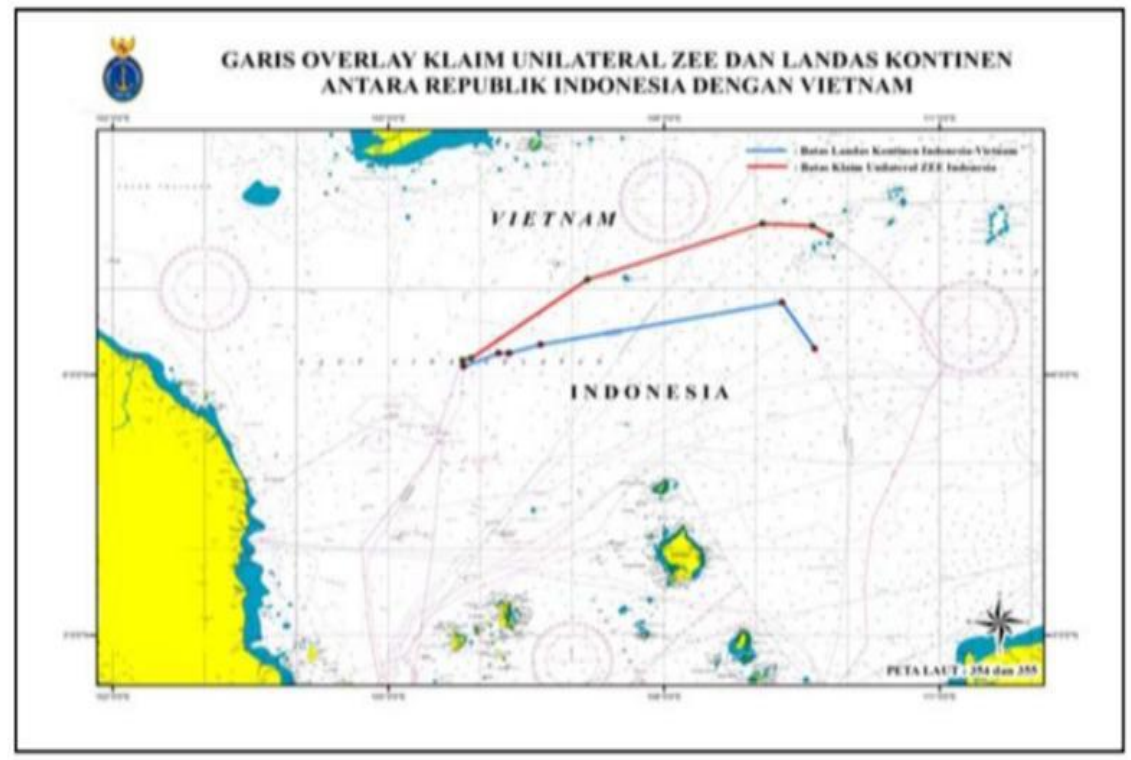

Figure 1 - Indonesian klaim through EEZ border with Vietnam (Source: Pushidrografi and Oseanografi of Navy, 2016)

North of Natuna Sea, which is surrounded by several countries, has the potential to have a conflict due to bordering and directly intersecting the boundaries of the country's Economic areas. Beginning in 1947 when the Chinese government published its national territory by publishing the Nine-Dash Line map and Indonesia were affected by these claims which caused the ZEEI (Indonesian Exclusive Economic Zone) in the North Natuna Sea to overlap with areas considered as traditional fishing ground by the Chinese government. The Indonesia-Vietnam sea boundary dispute and Chinese unilateral claims based on the Nine Dash Line map led to overlapping territorial claims at the EEZ in North Natuna. This condition caused Indonesia to suffer losses due to unilateral actions carried out by Vietnam and China that entered the ZEEI (Indonesian Exclusive Economic Zone) region in North Natuna and carried out fish theft by the fishing vessels of the two countries that were escorted by government ships or Coast Guard and even by military ships. Data from Koarmada I, recorded from 2015 to 2017 there have been arrests of 49 Vietnamese fishing vessels carrying out fishing activities in the North Natuna Sea, while Chinese fishing vessels have violated territories and fish theft at ZEEI (Indonesian Exclusive Economic Zone E) in North Natuna since 2010, 2015, The last 2016 was at the beginning of 2020 and these events have repeatedly occurred. Responding to illegal activities carried out by Vietnam and China at ZEEI (Indonesian Exclusive Economic Zone) in the North Natuna Sea, the government firmly stated that it was pursuing defense diplomacy and said it would not recognize the Nine Dash Line which is China's claim to the North Natuna Sea. 


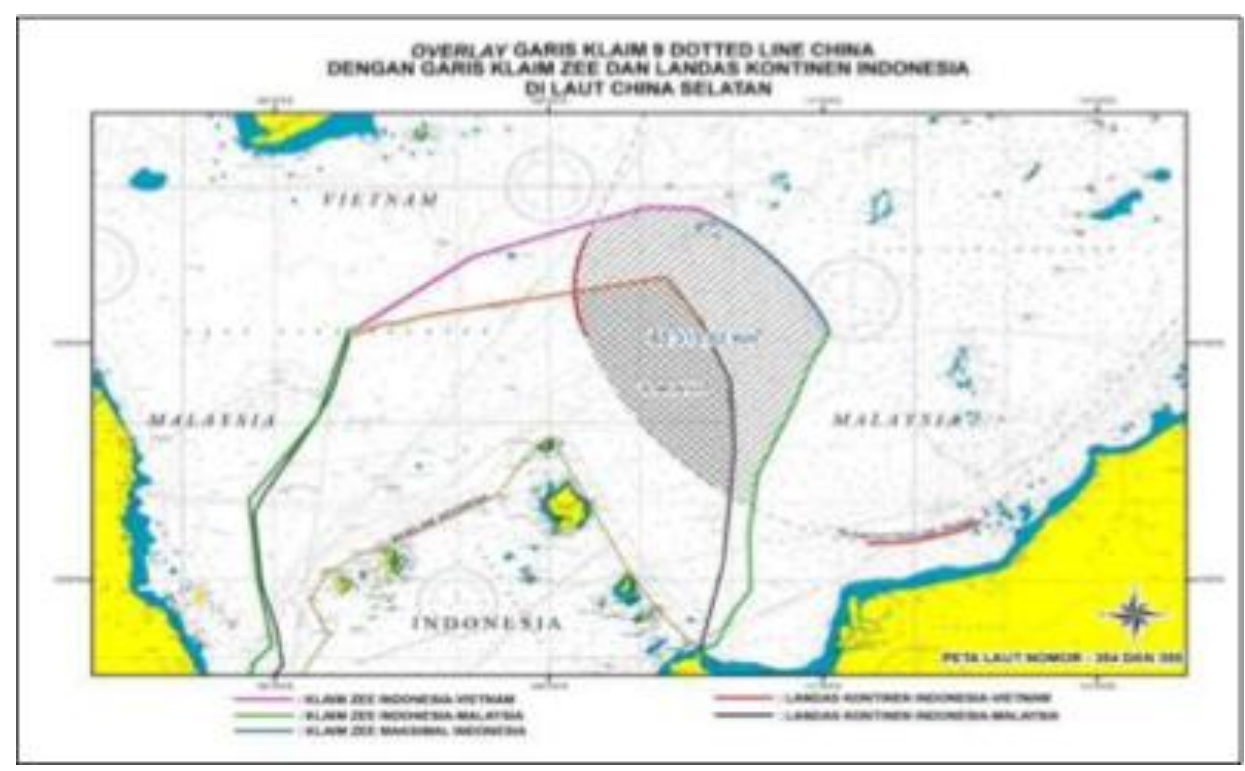

Figure 2 - Overlapping China's Nine Dash Line Claims in the North Natuna Sea (Source: Koarmada I, 2019)

The United Nations Convention on UNCLOS 1982, which release eight zoning regulations on sea law, followed up by the Indonesian government by making laws and regulations that serve as the legal basis for maritime security agencies in Indonesia in carrying out their roles, duties and functions. Six agencies that have patrol elements at sea namely the Navy, KPLP, KKP, Polairud, Customs and Indonesia Maritime Security Agency have carried out the roles, duties and functions of each institution in maintaining the integrity and sovereignty of the country at or through the sea, but in carrying out these tasks still it is partial so that good communication has not been established between agencies, besides that limited resources both defense equipment and human resources and a long bureaucratic structure in completing tasks cause slow handling of law enforcement at sea. A model of maritime policy integration is needed that can accommodate each agency so that there is synergy in the implementation of tasks in the field in realizing government programs to make Indonesia a global maritime axis.

The TNI (National Army) as the main tool of national defense and in accordance to the mandate of the Act of the Republic of Indonesia Number 34 of 2004 concerning on the TNI has clearly described the role, functions and duties of the TNI. Faced with the problem in Natuna, then as an application of military power, at least the task and responsibility must be handed over to the Navy supported by the Air Force. Specifically for the Indonesian Navy as a means of national defense at sea carrying out its duties the Natuna Sea and in EEZ guided by Article 9 of the Law of the Republic of Indonesia Number 34 of 2004 concerning to TNI. Article 9 letter $b$ states the purpose of law enforcement and maintaining security are all forms of activities related to law enforcement at sea in accordance with the authority of the Navy (constabulary function). The authority of the Navy (constabulary function) that applies universally so that the task given to the Navy is in accordance with the provisions of UNCLOS 1982 in article 73, article 110, article 111 and article 224. The authority and obligation of the Navy to carry out law enforcement in the Indonesian territorial waters, additional zones, continental shelf and the Indonesian Exclusive Economic Zone but are limited to the realm of pursuit, arrest, investigation, case investigation, and surrender to the prosecutor's office for prosecution to avoid prosecution the existence of a court by the Navy itself. The ability to overcome and secure the territorial sovereignty of the nation is a form of the sovereignty of the Indonesian state which is highly determined by military power as a function of national defense Although non-military forces such as KPLP, Immigration, Customs, Polairud, KKP and Indonesia Maritime Security Agency as supporting partners in the field of state security, so the two forces must support each other and provide information 
about the situation and condition of the sea, especially in the Natuna region and Indonesia's Exclusive Economic Zone in Natuna North.

In the Republic of Indonesia Act No. 17 of 2008 concerning Shipping in article 276 paragraph 1 and 2 states that to guarantee the implementation of safety and security at sea carried out the function of guarding and enforcing the laws and regulations at sea and the beach which function is carried out by sea and coast guards (Sea and Coast Guard). Although RI Law No. 17 of 2008 concerning Shipping has stated that related to the safety and security of shipping in Indonesian sea areas is carried out by the Sea and Coast Guard, as stipulated in article 4 regarding the scope of the enactment of this Act in Indonesian waters. The territorial waters of Indonesia as stated in article 3 paragraph 1 of Republic of Indonesia Act Number 6 of 1996 concerning Indonesian Waters include the Indonesian territorial sea, archipelago waters and inland waters. Territorial sea is a sea lane measured by 12 (twelve) nautical miles measured from the baselines of the Indonesian archipelago. Furthermore, the sea area is emphasized in Article 6 of the Republic of Indonesia Law No. 32 of 2014 concerning Marine Affairs, stating that the sea area consists of territorial waters and jurisdictions as well as the high seas and seabed areas. The territorial waters include inland waters, archipelagic waters and territorial seas with a sea width of 12 nautical miles measured from the baseline. The jurisdiction area includes the Additional Zone measured 24 nautical miles from the starting line, the Indonesian Exclusive Economic Zone is measured as wide as 200 nautical miles from the starting line and the Continental Platform are measured 200 miles beyond the baseline which is emphasized again in Article 1 point (a) of the Republic of Indonesia Act Number 1 of 1973 concerning the Indonesian continental shelf which states that the depth of the Indonesian continental shelf reaches a depth of 200 meters or more. The Unitary State of the Republic of Indonesia has sovereign rights in the territorial waters, certain jurisdiction rights in the Additional Zone and sovereign rights in the Exclusive Economic Zone and Continental shelf in accordance with statutory provisions and international law.

According to the above about concerning sea areas related to the duties of the Sea and Coast Guard in safeguarding the security and safety of shipping in the territorial waters of Indonesia, which structurally the Sea and Coast Guard are under martyrdom and in fact the formation of the Sea and Coast Guard has not been followed up on facilities and owned infrastructure so that until now to follow up regarding the safety and security of shipping are carried out by the KPLP. Therefore, after the issuance of the Republic of Indonesia Act Number 17 of 2008 which has been 12 years old has not been realized, while the problems of port safety and security of the Indonesian sea area continue to be a very dangerous threat to the territorial waters of Indonesia. For example such as the existence of ship collisions at sea and the entry of prohibited goods such as narcotics cannot be handled optimally. About other things that need attention about the delay of the Sea and Coast Guard is influenced by the wishes of the government in this case the Ministry of Sea Transportation or Director General of Hubla who have not yet proposed the concept of the Sea and Coast Guard that is expected, because the desired Sea and Coast Guard model is very important because each country has a different interpretation of the duties and functions of the Sea and Coast Guard. At least the government will immediately issue lower-level legal or regulatory products under the Law for the establishment of the Sea and Coast Guard, which are confronted with issues of port safety and shipping security (sea area).

Today, the military forces (Navy and Air Force) and non-military forces in the form of government vessels (KPLP, Immigration, Customs, Polairud, KKP and Indonesia Maritime Security Agency) are considered to be still not integrated and synergistic in carrying out their functions, duties and roles so that they are impressed more inclined to put forward the sectoral egos of each other, this must be integrated with a government policy in the form of a model of policy integration in the maritime sector.

Dissecting the problems at Natuna, the analysis knife which used in this study was adopting public policy theory by James Anderson and George C Edwar and legal policy theory. Some public policy experts such as Thomas R. (2005) Dye suggest that public policy is whatever the government chooses to do or not to do. Public policies are binding decisions 
for many people at the strategic or outline level made by the public authority holder (Soeharto, 2008). While Anderson (2003) states that public policy is a process of activity consisting of problem formulation, policy formulation, policy determination, implementation and evaluation. Soebarsono (2005) writes that a policy that has been recommended to be chosen by policy makers cannot guarantee the success of the policy in its implementation. There are several variables that influence the successful implementation of policies both individual and group or institutional. The implementation of a program will involve various efforts made by policy makers to influence the behavior of policy implementers so that they are willing to provide services and manage target groups. George C. Edward in Soebarno, states that the implementation of public policy is influenced by four dimensions namely the dimensions of communication, resources, disposition and bureaucratic structure. The four dimensions need to be elaborated so as to produce a maritime integration policy formulation in Natuna in the context of law enforcement and state sovereignty.

The act of theft of living natural resources in the Indonesian Exclusive Economic Zone in the North Natuna Sea by foreigners is a criminal offense so that it is necessary to apply criminal law by the state. Criminal law policy or criminal policy is part of a criminal policy which is a systematic and integrated effort carried out jointly between the community and the government in the context of overcoming crime. According to Barda Nawawi Arif (2007) said that criminal policy or criminal law policy is an integral part of criminal policy (criminal policy) carried out in a country, by applying criminal law. Whereas the non-penal policy is carried out by preventing crime without using the crime and influencing the public's view of crime and punishment through mass media. The positive legal instruments used by each law enforcement agency at sea are the instruments used in carrying out their functions, duties and roles. However, there is no maritime policy modeling that can be used in integrating and synergizing each agency in implementing law enforcement and sovereignty at sea.

After processing the data obtained from the informants as well as literature review and strengthened with policy theory and legal policy theory in this study, it produces some findings in the form of a maritime policy integration model that can be applied in the perspective of defense and security in Natuna. In dealing with military and non-military threats from a defense perspective in Natuna, an integrated maritime policy in Natuna is needed. As stated above, the problem that is vulnerable and often occurs in North Natuna Sea is the high illegal fishing activities in the border waters by foreign parties. Efforts to reduce the theft of fish by increasing the presence of patrol vessels in the Natuna Sea border region so that the need for policy formulation in the form of increased operational costs including fuel support for task forces. The vast area of Natuna Sea waters requires cooperation in terms of joint patrols with several maritime security agencies and joint patrols in neighboring countries in each region. It is necessary to re-map the marine patrol sector by adding routes that are potentially vulnerable to fish theft activities in the Natuna Sea so that it is possible to minimize or even close the criminal acts that occur at sea. The policy steps need to be balanced with the improvement of infrastructure, defense equipment, and professionalism of the Indonesian Navy troops serving in the Natuna Sea.

With the division of tasks facing the violation of the territory by foreign military vessels or the theft of biological resources by foreign fishing vessels can use the strength of the Navy. Through the preparation of long-term defense patterns, the development and enhancement of military defense forces with the Navy supported by the Air Force as the leading sector, all components of the state in the maritime and maritime service industries as a reserve component, holding an integrated Tri Matra TNI exercise, bilateral and multilateral exercises and conducting shows off force in the form of a degree of strength in the form of day-to-day marine operations and sea combat alert operations in Natuna and ZEEI (Indonesian Exclusive Economic Zone) in North Natuna so that indirectly the military's function as defense will be more dominant. The implementation of the title of operation can be carried out with a waiting pattern with a surveillance system that utilizes the presence of coastal radars as surveillance or the use of Navy maritime patrol aircraft and Indonesian Air Force aircraft as an extension of the eyes and ears for ships (KRI) owned by the Navy in carrying out patrols. The model offered by formulating an integrated maritime policy in a 
container of the Integrated Defense and Sea Security Task Force between relevant ministries (military and non-military) to strengthen national defense in the border region in Natuna and Indonesia's Exclusive Economic Zone as a form of defense diplomacy.

The long-term of the impact of national defense on maritime sovereignty in the North Natuna Sea through the use of resources so as to realize the achievement of maritime sovereignty. The medium-term impact is that the presence of the KRI in the region will certainly be able to maintain the country's sovereignty in the border region of Indonesia's Exclusive Economic Zone in Natuna. The increase of Indonesian Navy (KRI) ships and Navy Airplanes (Cassa), then they can more effectively to implement sea defense and security and the application of a special policy on Natuna that is comprehensive by the central and regional governments where each institution such as the Ministry of Defense, The Ministry of Maritime Affairs and Fisheries, the Ministry of State Affairs and the Ministry of Tourism collaborate in empowering the Natuna region in the economic, tourism and defense and security sectors. While the short-term impact is to improve the management of maritime potential in Natuna by assisting fishing groups through the construction of large fishing vessels so that they can catch fish up to the Indonesian Exclusive Economic Zone in Natuna escorted by the Navy so that it has an impact on improving the economy fishermen and improve fishing ports and if possible export ports in the Natuna region.

One of the Navy's responsibilities is to carry out maritime diplomacy. Maritime Diplomacy that conducted by the Indonesian Navy is a form of implementation of one of the world's maritime axis pillars related to communication, first is to introduce Indonesian sea destinations to neighboring countries, carry out maritime sports competitions so that the objectives can indirectly convey boundaries the territory of the country especially those bordering the sea borders of neighboring countries. The second is to carry out exhibitions that are naval. Third is an international screen tourism rally carried out by using Indonesian waters as a race track indirectly can become the foundation for the formation of an Indonesian sail tourism track that covers all Indonesian waters that have various marine tourism destinations while realizing Indonesia's maritime diplomacy mission. Exemption from import duty for importing Yacht vessels (required to submit guarantees to the Head of Customs Office where importing Temporary Imported Goods) is a problem that cannot be solved because it involves the task domain and the work area of other agencies (Setlight, 2011). Fourth, Maritime Tourism is one of the leading tourism products that can be sold by the Indonesian government that can contribute greatly to the achievement of foreign tourists visiting Indonesia.

Koarmada I and his staff in this matter, the Maritime Potential Office has a communication role in Building the Maritime Culture of the people in Natuna as a form of implementing or translating one of the pillars of the world's maritime axis in the field of military defense communication. Furthermore, according to the First TNI Admiral, Irvansyah, $\mathrm{SH}$ said that in Building Maritime Culture as a form of translation of one of the pillars of the world's maritime axis related to resources, namely First by utilizing the role of the Maritime Potential Office organization that has been owned by the Navy to carry out the development of empowerment of defense territories sea so that all forms of threats that are detected and prevented as early as possible and the reserve and supporting components can be prepared earlier so that they are still able to deal with all forms of threats to the country's sovereignty. The second is to always emphasize the operational elements (KRI) that operate if leaning on the naval bases can work together with the bases to disseminate sea defense to the fishing and coastal communities.

The existence of Indonesia Maritime Security Agency as a maritime security agency that participated in carrying out safeguards and supervision through patrol activities in protecting Natuna waters, besides Indonesia Maritime Security Agency also carried out maritime culture development to the community by forming Poksimar (Maritime Potential Group) consisting of 35 fishermen from Cemaga Village, Natuna. Indonesia Maritime Security Agency seeks to encourage the active role of the community in assisting the delivery of information related to threats of violence at sea, violations of navigation, violations of the law, and threats to marine resources. Communication between Indonesia Maritime 
Security Agency and fishing communities that are structural and cultural needs to be supported by the preservation of adequate public service facilities such as access roads, lighting, power plants, and health centers. Social and cultural improvement as a source of nationalism unification between Indonesia Maritime Security Agency and fishermen can be in the form of collaborative research into the potential of untouched cultivation. This can encourage regular joint research and workshop policies. Efforts to preserve social communication through research or can be carried out by exploring and researching the potential of marine resources contained in the North Natuna Sea.

Maritime culture in social interaction needs to be understood comprehensively, especially which related to socio-cultural security. First Admiral Nursyawal Embun explained that maritime culture is a pattern of life and community interaction that depended on the sea. The problem that arises in understanding this maritime culture is that the sea is not represented in the life of the local community in a dominant manner where the desire of the community to exploit marine resources is still very low. The formula in the form of a solution to the problem is the attitude of Indonesia Maritime Security Agency's willingness to socialize the types of commercial business that can attract economic benefits routinely every semester to the community by continuing to involve the local government as a stake holder to facilitate the follow up of any previous socialization or training. The policy that needs to be pursued is to strive for marine-based nationalism in students and young people of productive age. This can be done by carrying out various briefings on local maritime insight, socializing rights and obligations as well as criminal actions at sea for fishermen and residents living on the coast, and training in marine entrepreneurship. Indonesia Maritime Security Agency has its own socio-cultural disposition in cracking down on marine pollution cases that have sacrificed the coastal communities of Natuna Regency and are carried out by private companies and SOEs. Indonesia Maritime Security Agency plays an active role in taking precautions against cases of environmental pollution. Indonesia Maritime Security Agency will carry out inspection and action against ships suspected of polluting the environment in accordance with the information obtained. Indonesia Maritime Security Agency also seeks to minimize the impact of environmental pollution. This was proven by Indonesia Maritime Security Agency who continued to train his personnel in handling this incident, one of which Indonesia Maritime Security Agency collaborated with in handling the effects of oil spills at sea.

The policy that Indonesia Maritime Security Agency continues to promote in this case is to be proactive in summoning, checking and detaining parties who pollute the sea. The implementation of the policy is carried out by means of prevention through the establishment of social services and information with the public regarding various suspicions of the marine environment, measures against measurable pollution perpetrators, and mobilization of local governments in handling affected pollution.

Formulation of national policies and regional policies in the field of security and safety of Natuna Regency waters in the bureaucratic structure dimension requires Indonesia Maritime Security Agency participation as a form of social interconnection and good national political culture. Law of the Republic of Indonesia Number 32 of 2014 in article 62, states that in carrying out its duties Indonesia Maritime Security Agency carries out the function of "compiling national policies in the field of security and safety in Indonesian territorial waters and Indonesian jurisdictions" to be the first reference in Indonesia Maritime Security Agency's participation in the formulation of regional policies related to maritime affairs. Another consideration of the bureaucratic structure that strengthens Indonesia Maritime Security Agency's participation in upholding water security and safety policies in Natuna Regency is to review and carry out Indonesia Maritime Security Agency's function as an agency that has legal rights and authority over maritime sovereignty. Sea law enforcement against foreign fishing vessels that carry out illegal fishing theft in Indonesia's Exclusive Economic Zone can be resolved by cross-agency communication so that a synergy and harmonization in maritime defense management will be realized.

Integration of maritime policy in the security perspective of this model can be carried out approaches to the aspects of ideological security, political security, economic security and socio-cultural security that continue to refer to the national policy sector five pillars of the 
world's maritime axis. Broadly speaking, the ideological security model through education and understanding of marine affairs carried out by the Natuna Regency Government by cooperating with relevant agencies in the maritime such as the Navy, Indonesia Maritime Security Agency, KKP, Polairud, KPLP, Customs and private sector resulting in the exchange of information about the region areas prone to violations and conflicts at Natuna waters and the Indonesian Exclusive Economic Zone by foreign fishermen or foreign government vessels as a result of the unresolved sea area boundaries with neighboring countries so that the fishing community in Natuna Regency understands the importance of security which is influenced by the ability to think politically that the region Natuna must be safe from the threat of exploiting marine resources by other countries. Thus it will improve the ability of the ideological way of thinking of fishermen that the sea will be safe and the sovereignty of the Unitary Republic of Indonesia is a must.

In the aspect of political security, the maritime policy integration model is implemented by enhancing the capabilities of the fishermen community's human resources through education so as to increase graduate graduates from fishing families as a portrait of regional political security which is a form of cooperation between all Natuna regency government agencies together to realize the restoration of political rights fishing families based on social justice for all Indonesian people. Provisioning and enhancing marine skills for fishermen as well as providing ship procurement assistance by the local government or working together with the private sector, providing and organizing public service units for fishing communities such as puskesmas, hospitals, places of worship and land transportation facilities. So that the capabilities of Fishermen's HR in Natuna politically greatly affect the development of security in the Natuna region because they have the same perception about marine as a source of community life.

In the aspect of economic security the maritime policy integration model is strongly influenced by economic principles, especially the Indonesian Exclusive Economic Zone in Natuna. The living natural resources in the Indonesian Exclusive Economic Zone must be managed well by the Natuna Regency government through enhancing the capabilities of fishermen and increasing fishing ports as the economic wheel for fishermen and marine industry activists in Natuna so that the increasing number of Indonesian fishermen in the Exclusive Economic Zone of Indonesia in Natuna will improve the regional economy and the presence of the fishermen and community watchdog groups in the Indonesian Exclusive Economic Zone in Natuna can be used as eyes and ears to provide information about security in the Natuna Sea and Indonesia's Exclusive Economic Zone so that the government in this case law enforcement officers in the maritime field can move quickly to deal with maritime security so that it can save biological resources in the region from illegal activities by foreign fishing vessels, from other aspects indirectly also improve community welfare fishing community in the Natuna area which also improves the regional economy.

In the aspect of socio-cultural security the model can be implemented by encouraging the local government of Natuna Regency to revive traditional activities, especially fishing or coastal communities, they will go to sea or finish fishing any time in the form of traditional ceremonies so as to create a regional repertoire that revives cultures areas that have long been abandoned by cooperating with the regional or central tourism office to publicize and promote these activities in the region or nationally. If this is carried out, then indirectly all the traditional activities are known by all Indonesian people that the Natuna area fishermen have a marine culture as fishermen who are able to catch fish up to ZEEI (Indonesian Exclusive Economic Zone) in North Natuna.

The maritime policy integration model in Natuna formed in its implementation in the form of the Maritime Defense and Security Task Force is equipped with a legal basis in the form of international and national legal frameworks in the form of legislation, Standard Operating Procedures (SOP), Rule of Engangment (ROE) or rules of engagement. The government made the main ROE as the ROE implementation in translating and supporting the tasks, functions and roles of each agency in supporting the government's policy to realize Indonesia as the world's maritime axis with five pillars. 


\section{CONCLUSION AND RECOMMENDATIONS}

The maritime policy integration model at Natuna in the perspective of defense and security faces military and non-military threats in the form of territorial violations and theft of biological resources (fish) in the Natuna Sea and ZEEI (Indonesian Exclusive Economic Zone) in North Natuna by foreign fishing vessels (Vietnam and China ) escorted by government ships (Coast Guard) and even by military ships far behind, prioritizing the use of army forces with the Navy supported by the Air Force as a leading sector in one Luat Defense and Security Task Force, assisted by state components in the maritime and industrial fields maritime services as a backup component. Holding an Integrated Tri Matra $\mathrm{TNI}$ exercise, bilateral and multilateral exercises as well as a show off force in the form of a degree of force in the form of daily sea operations and sea combat standby operations in the Natuna Sea and ZEEI (Indonesian Exclusive Economic Zone) so that indirectly the military function as defense will be more dominant. In the implementation of the degree of day-to-day marine operations and sea combat alert operations can be carried out with a waiting pattern with a surveillance system that utilizes the presence of coastal radars as surveillance or the use of Indonesian Navy maritime patrol aircraft and Indonesian Air Force aircraft as an extension of the ships (KRI) ) owned by the Navy in carrying out patrols.

The maritime policy integration model faces non-military threats in the form of security threats to ideology, politics, economics and socio-culture as a result of regional violations and fish theft by Vietnamese and Chinese fishermen in the North Natuna Sea and ZEEI (Indonesian Exclusive Economic Zone) escorted by government vessels or Coast Guard that continues to repeat, then the model offered by forming a container of the Defense and Security Task Force, using the strength of non-military maritime security agencies or government vessels (Indonesia Maritime Security Agency, KKP, Polairud, KPLP and Customs) supported by the Navy force and the Air Force.

The maritime policy integration model in Natuna formed in its implementation in the form of the Maritime Defense and Security Task Force is equipped with a legal basis in the form of international and national legal frameworks in the form of legislation, Standard Operating Procedures (SOP), Rule of Engagement (ROE) or rules involvement. The government made the main ROE as a guide for making ROE implementation in translating and supporting the tasks, functions and roles of each agency in defense and security to support the government's policy to realize Indonesia as a world maritime axis with five pillars.

Based on the results of research, discussion and conclusions, the recommended recommendations are:

1. The government needs to issue a plan for maritime integration policy in Natuna through a defense and security model using military and non-military forces;

2. The government needs to strengthen the existence of Indonesia Maritime Security Agency as a maritime security agency that will become the forerunner to the Indonesian Coast Guard;

3. The government needs to issue a maritime policy in the form of ROE to protect the Marine Defense and Security Task Force in carrying out its duties, functions and roles in order to enforce the law and maintain security in the sea territory of national jurisdiction.

\section{REFERENCES}

1. Anderson, James, Public Policy making Fifth, USA: Houghton Miffin Company, 2003.

2. Arif, Barda Nawawi, Kebijakan Legislatif Dalam Penanggulangan Kejahatan Dengan Pidana Penjara, Semarang: Badan Penerbitan Universitas Diponegoro Semarang, 1997.

3. Dahuri, R et al, Pengelolaan Sumber Daya Wilayah Pesisir and Lautan Secara Terpadu, Jakarta: PT. Pradnya Paramita, 2001.

4. Dye, Thomas R, Understanding Public Policy, Eleventh edition, New Jersey: Pearson Prentice Hall, 2005. 
5. Kartasapoetra G. and Kartasapoetra RG., Indonesia Dalam Lingkaran Hukum Internasional (dari Abad ke Abad), Bandung: PT Satelit, 1987.

6. Mochtar Kusumaatmadja and Etty R. Agoes, Pengantar Hukum Internasional, Bandung: Alumni, 2010.

7. Parthiana, I Wayan, Pengantar Hukum Internasional, Bandung: PT Mandar Maju, 2003.

8. Soebarsono, Analisis Kebijakan Publik Konsep, Teori and Aplikasi, Yogyakarta: PT Pustaka Pelajar, 2005.

9. Soeharto, Analisis Kebijakan Publik, Yogyakarta: PT Pustaka Pelajar, 2008.

10. Sugiyono, Metote Penelitian Administrasi. Bandung: CV. Alfabeta, 2004.

11. Soebarsono, 2005, Analisis Kebijakan Publik Konsep, Teori and Aplikasi, Yogyakarta: PT Pustaka Pelajar.

12. Pusat Hidrografi and Oseanografi Angkatan Laut, Batas Maritim Indonesia Dengan Negara Tetangga Edisi tahun 2016.

13. Subagyo, Joko, Hukum Laut Indonesia, Jakarta, Rineka Cipta, cetakan ke - 4, 2009.

14. Undang - Undang Republik Indonesia Nomor 34 tahun 2004 Tentang Tentara Nasional Indonesia.

15. Undang - Undang Republik Indonesia Nomor 5 Tahun 1983 Tentang Zona Ekonoi Eksklusif.

16. Undang - Undang Republik Indonesia Nomor 17 Tahun 2008 Tentang Pelayaran.

17. Undang-Undang Republik Indonesia Nomor 32 Tahun 2014 tentang Kelautan.

18. Undang - Undang Republik Indonesia Nomor 6 Tahun 1996 Tentang Perairan Indonesia.

19. Undang-Undang Republik Indonesia Nomor 17 Tahun 1985 Tentang Ratifikasi UNCLOS 1982.

20. Undang-Undang Republik Indonesia Nomor 1 Tahun 1973 Tentang Landas Kontinen Indonesia.

21. Undung-Undang Nomor 17 Tahun 2007, Tentang Rencana Pembangunan Jangka Panjang Nasional 2005-2025.

22. United Nation Convention on the Law Of Sea 1982.

23. Setlight, Mercy Maria Magdalena, "Peraturan Presiden Nomor 105 Tahun 2015 Tentang Kunjungan Kapal Wisata (Yacht) Asing ke Indonesia dalam Perspektif Pengembangan Pariwisata di Kabupaten Kepulauan Sangihe." LEX ET SOCIETATIS 4.7, 2011.

24. Holsti, K. J "National Role Conceptions In The Study Of Foreign Policy", International Studies Quarterly, Vol 14, Issue 3, 1970. 